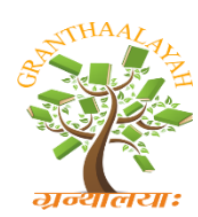

INTERNATIONAL JOURNAL OF RESEARCH GRANTHAALAYAH A knowledge Repository

Social

\title{
A STUDY ON SOCIAL ADJUSTMENT AMONG HIGHER SECONDARY SCHOOL STUDENTS AND ITS IMPACT ON THEIR ACADEMIC ACHIEVEMENT IN COIMBATORE DISTRICT
}

\author{
P.Priya Packiaselvi ${ }^{* 1}$, Ms.Malathi.V.A ${ }^{2}$ \\ ${ }^{* 1}$ MEd Scholar, RVS College of Education, India \\ ${ }^{2}$ Assistant Professor in Computer Science, RVS College of Education, India
}

DOI: https://doi.org/10.29121/granthaalayah.v5.i6.2017.2056

\begin{abstract}
Every human being seeks adjustment to various situations. He constantly makes efforts to adjustment himself to his surroundings because a wholesome adjustment is essential for leading a happy life and going satisfaction. Social adjustment to other people is general and to the group with which they are identified is particular. The main motive of the study is to find out the social adjustment among higher secondary school students and its impact on academic achievement in Coimbatore Educational District. This research is under taken with a view to examining the relationship with social adjustment and general achievement of different high school students with a sample size 148 . The investigation is analyzed by the descriptive analysis and differential analysis. The result concluded from the study that there is no substantial change with respect to mother tongue, gender, location of school, type of family, educational qualification of parents, occupation of parents, monthly income of parents in their mean score of social adjustment and academic achievement. This study might enable teachers and administrators to look for ways of enhancing social adjustment among the students from higher secondary school and its impact on their academic achievement in Coimbatore District.
\end{abstract}

Keywords: Social Adjustment; Achievement; Education; Academic.

Cite This Article: P.Priya Packiaselvi, and Ms.Malathi.V.A. (2017). "A STUDY ON SOCIAL ADJUSTMENT AMONG HIGHER SECONDARY SCHOOL STUDENTS AND ITS IMPACT ON THEIR ACADEMIC ACHIEVEMENT IN COIMBATORE DISTRICT." International Journal of Research - Granthaalayah, 5(6), 458-463. 10.29121/granthaalayah.v5.i6.2017.2056.

\section{Introduction}

Social adjustment defined as the variation of an individual to the social environment. Adjustment may take place by adjusting the self to the situation or by fluctuating the surroundings. (Campbell, Psychiatric Dictionary, 1996). Social adjustment as a significant sign of psychology health is a subject fascinating the consideration of many psychologists. Social growth is the most 
significant feature of one's growth and it is assimilated through the relationship with others particularly with the parents, peers and the educators, and it is the measuring benchmark of social growth related to the person's adjustment with him/herself and others. The main scope of the study is the students' academic achievement can be projected on the base of the students' social adjustment and feasible solutions will be given based on the findings analyzed. This study was conducted on a sample of 148 students only. It is limited in Coimbatore District only. The hypotheses were framed to identify any significant mean score difference between gender, medium of instruction, locality, mother tongue among higher secondary school students. In addition to, to identify significant difference towards social adjustment based on the gender, medium of instruction, the location of the school, type of the school, nature of the school, type of family, educational qualification of father, educational qualification of mother, occupation of father, occupation of mother, monthly income of father and monthly income of mother.

\subsection{Objectives of the Study}

There are two main types of objectives undertaken by the investigator in this study work.

\subsubsection{General Objectives}

- To study the social adjustment among higher secondary school students and its impact on their academic achievement in Coimbatore District.

- To adopt questionnaire on social adjustment among higher secondary school students.

\subsubsection{Specific Objectives}

- To find out the social adjustment among higher secondary school students.

- To find out the impact of personal variables like Mother Tongue, Gender, Medium of instruction, location of the school, type of the school, nature of the school, educational qualification of father, educational qualification of mother, monthly income of father, monthly income of mother, type of family on social adjustment among higher secondary school students.

\section{Research Design}

The investigator adopted survey method to study on social adjustment among higher secondary school students and its impact on their academic achievement in Coimbatore district. For this study a sample of 148 from 5 various schools which are situated in and around Coimbatore district in Tamilnadu were selected by the investigator using simple random sampling technique.

Table 1: Distribution of Samples based on Variables

\begin{tabular}{|c|c|c|c|c|c|}
\hline S.NO & Category & Subgroups & Number & \% & Total \\
\hline \multirow{3}{*}{1.} & \multirow{3}{*}{ Mother Tongue } & Tamil & 119 & $80.4 \%$ & \multirow{2}{*}{148} \\
\cline { 3 - 5 } & \multirow{3}{*}{2.} & Others & 29 & $19.6 \%$ & \multirow{2}{*}{148} \\
\hline & Gender & Boys & 110 & $74.3 \%$ & \\
\hline & Location of the & Girls & 38 & $25.7 \%$ & \\
\hline
\end{tabular}




\begin{tabular}{|c|c|c|c|c|c|}
\hline 3. & School & Rural & 66 & $44.6 \%$ & 148 \\
\hline \multirow[t]{2}{*}{4.} & \multirow{2}{*}{$\begin{array}{l}\text { Medium of } \\
\text { Instruction }\end{array}$} & Tamil & 58 & $39.2 \%$ & \multirow[t]{2}{*}{148} \\
\hline & & English & 90 & $60.8 \%$ & \\
\hline \multirow[t]{2}{*}{5.} & \multirow[t]{2}{*}{ Type of the School } & Govt. & 77 & $52 \%$ & \multirow[b]{2}{*}{148} \\
\hline & & Private & 71 & $48 \%$ & \\
\hline \multirow[t]{2}{*}{6.} & \multirow{2}{*}{$\begin{array}{l}\text { Nature of the } \\
\text { School }\end{array}$} & Boys & 52 & $35.1 \%$ & \multirow[t]{2}{*}{148} \\
\hline & & Co-ducation & 96 & $64.9 \%$ & \\
\hline \multirow[t]{2}{*}{7.} & \multirow[t]{2}{*}{ Type of Family } & Nuclear Family & 127 & $85.8 \%$ & \multirow[t]{2}{*}{148} \\
\hline & & Joint Family & 21 & $14.2 \%$ & \\
\hline \multirow[t]{6}{*}{8.} & \multirow{6}{*}{$\begin{array}{c}\text { Educational } \\
\text { Qualification of } \\
\text { father }\end{array}$} & illiterate & 11 & $7.4 \%$ & \multirow[t]{6}{*}{148} \\
\hline & & School Level & 66 & $44.6 \%$ & \\
\hline & & Diploma & 26 & $17.6 \%$ & \\
\hline & & UG & 33 & $22.3 \%$ & \\
\hline & & PG & 11 & $7.4 \%$ & \\
\hline & & Others & 1 & $0.7 \%$ & \\
\hline
\end{tabular}

\begin{tabular}{|c|c|c|c|c|c|}
\hline \multirow[t]{6}{*}{9.} & \multirow{6}{*}{$\begin{array}{c}\text { Educational } \\
\text { Qualification of } \\
\text { mother }\end{array}$} & illiterate & 17 & $11.5 \%$ & \multirow[t]{6}{*}{148} \\
\hline & & School Level & 80 & $54.1 \%$ & \\
\hline & & Diploma & 22 & $14.9 \%$ & \\
\hline & & UG & 20 & $13.5 \%$ & \\
\hline & & PG & 5 & $3.4 \%$ & \\
\hline & & Others & 4 & $2.7 \%$ & \\
\hline \multirow[t]{6}{*}{10.} & \multirow{6}{*}{$\begin{array}{l}\text { Occupation of } \\
\text { Father }\end{array}$} & Agriculture & 13 & $8.8 \%$ & \multirow[t]{6}{*}{148} \\
\hline & & Business & 14 & $9.5 \%$ & \\
\hline & & Coolie & 31 & $20.9 \%$ & \\
\hline & & Government & 25 & $16.9 \%$ & \\
\hline & & Private & 64 & $43.2 \%$ & \\
\hline & & Others & 1 & $0.7 \%$ & \\
\hline \multirow[t]{6}{*}{11.} & \multirow{6}{*}{$\begin{array}{l}\text { Occupation of } \\
\text { Mother }\end{array}$} & Agriculture & 8 & $5.4 \%$ & \multirow[t]{6}{*}{148} \\
\hline & & Business & 18 & $12.2 \%$ & \\
\hline & & Coolie & 23 & $15.5 \%$ & \\
\hline & & Government & 23 & $15.5 \%$ & \\
\hline & & Private & 23 & $15.5 \%$ & \\
\hline & & House Wife & 53 & $35.8 \%$ & \\
\hline \multirow[t]{4}{*}{12.} & \multirow{4}{*}{$\begin{array}{l}\text { Monthly income of } \\
\text { Father }\end{array}$} & Below Rs.20000 & 13 & $8.8 \%$ & \multirow[t]{4}{*}{148} \\
\hline & & Rs.21000-Rs.30000 & 35 & $23.6 \%$ & \\
\hline & & Rs.31000-Rs.40000 & 46 & $31.1 \%$ & \\
\hline & & Above Rs.40000 & 54 & $36.5 \%$ & \\
\hline \multirow[t]{4}{*}{13.} & \multirow{4}{*}{$\begin{array}{l}\text { Monthly income of } \\
\text { mother }\end{array}$} & Below Rs.20000 & 82 & $55.4 \%$ & \multirow[t]{4}{*}{148} \\
\hline & & Rs.21000-Rs.30000 & 27 & $18.2 \%$ & \\
\hline & & Rs.31000-Rs.40000 & 20 & $13.5 \%$ & \\
\hline & & Above Rs.40000 & 19 & $12.8 \%$ & \\
\hline
\end{tabular}


Table 2: Scoring of Each item

\begin{tabular}{|c|c|c|c|c|c|c|c|}
\hline \multirow[t]{2}{*}{ S.No } & \multirow[t]{2}{*}{ Dimension } & \multirow[t]{2}{*}{ Question no. } & \multicolumn{5}{|c|}{ Scoring } \\
\hline & & & SA & $\mathbf{A}$ & $\mathbf{N}$ & D & SD \\
\hline 1. & Social Adjustment Scale & $\begin{array}{l}1 \text { to } 12,15,16,18 \text { to } \\
23,25,27,28,29\end{array}$ & 5 & 4 & 3 & 2 & 1 \\
\hline 2. & Social Adjustment Scale & $13,14,17,24,26$ & 1 & 2 & 3 & 4 & 5 \\
\hline
\end{tabular}

Table 3: Ranks assigned for the scores

\begin{tabular}{|l|l|}
\hline \multicolumn{2}{|c|}{ Social Adjustment } \\
\hline Scores & Rank \\
\hline 29 to 67 & Low \\
\hline 68 to 105 & Moderate \\
\hline 106 to 145 & High \\
\hline
\end{tabular}

Table 4: Ranks assigned for the Academic Achievement scores

\begin{tabular}{|l|l|}
\hline \multicolumn{2}{|c|}{ Academic Achievement Scores } \\
\hline Scores & Rank \\
\hline Less than 45 & Low \\
\hline 46 to 63 & Moderate \\
\hline 64 to 80 & High \\
\hline
\end{tabular}

\section{HYPOTHESIS 1:}

There will be a significant mean score difference towards social adjustment between boys and girls among higher secondary school students.

Table 5: Frequency and percentage difference towards social adjustment between boys and girls among higher secondary school students

\begin{tabular}{|c|c|c|c|c|c|c|c|}
\hline \multirow[t]{2}{*}{ Gender } & \multicolumn{2}{|c|}{ Low } & \multicolumn{2}{|c|}{ Moderate } & \multicolumn{2}{|c|}{ High } & \multirow[b]{2}{*}{ Total } \\
\hline & $\mathbf{N}$ & $\%$ & $\mathbf{N}$ & $\%$ & $\mathbf{N}$ & $\%$ & \\
\hline Boys & 1 & 0.91 & 47 & 42.72 & 62 & 56.36 & 110 \\
\hline Girls & 0 & 0 & 8 & 21.05 & 30 & 78.95 & 38 \\
\hline
\end{tabular}

It is conclude from the Table 5 that amid the boys, $56.36 \%$ of them have high Level, $42.72 \%$ of them have moderate Level and $0.91 \%$ of them have low level of social adjustment. Similarly, amid the girls, $78.95 \%$ of them have high Level and $21.05 \%$ of them have moderate Level. The result inferred that majority of the boys and girls have high level of social adjustment. But comparatively, the girls have high level of social adjustment than the boys.

\section{HYPOTHESIS 2:}

There will be a significant mean score difference towards social adjustment between Tamil and English medium among higher secondary school students. 
Table 6: Frequency and percentage difference towards social adjustment between Tamil and English medium among higher secondary school students

\begin{tabular}{|l|l|l|l|l|l|l|l|}
\hline \multirow{2}{*}{ Medium of Instruction } & Low & \multicolumn{3}{l|}{ Moderate } & \multicolumn{2}{l|}{ High } & \multirow{2}{*}{ Total } \\
\cline { 2 - 10 } & $\mathbf{N}$ & $\boldsymbol{\%}$ & $\mathbf{N}$ & $\mathbf{\%}$ & $\mathbf{N}$ & $\boldsymbol{\%}$ & Tot \\
\hline Tamil & 0 & 0 & 21 & 36.21 & 37 & 63.79 & 58 \\
\hline English & 1 & 1.11 & 34 & 37.78 & 55 & 61.11 & 90 \\
\hline
\end{tabular}

It is conclude from the Table 6 that amid the Tamil medium students, $63.79 \%$ of them have high Level and $36.21 \%$ of them have moderate Level of social adjustment. Similarly, amid the English medium students, $61.11 \%$ of them have high Level, $37.78 \%$ of them have moderate Level and $1.11 \%$ of them have low level of social adjustment. The result inferred that majority of the Tamil and English medium have high level of social adjustment. But comparatively, the Tamil medium students have high level of social adjustment than the English medium students.

\section{HYPOTHESIS 3:}

There will be a significant mean score difference towards social adjustment between the rural and urban school among higher secondary school students.

Table 7: Frequency and percentage difference towards social adjustment between the rural and urban school among higher secondary school students.

\begin{tabular}{|c|c|c|c|c|c|c|c|}
\hline \multirow[t]{2}{*}{ Location of the School } & \multicolumn{2}{|c|}{ Low } & \multicolumn{2}{|c|}{ Moderate } & \multicolumn{2}{|c|}{ High } & \multirow[b]{2}{*}{ Total } \\
\hline & $\mathbf{N}$ & $\%$ & $\mathbf{N}$ & $\%$ & $\mathbf{N}$ & $\%$ & \\
\hline Urban & 1 & 1.22 & 33 & 40.24 & 48 & 58.54 & 82 \\
\hline Rural & 0 & 0 & 22 & 33.33 & 44 & 66.67 & 66 \\
\hline
\end{tabular}

It is conclude from the Table 7 that amid the urban school students, 58.54\% of them have high Level, $40.24 \%$ of them have moderate Level and $1.22 \%$ of them have low level of social adjustment. Similarly, amid the rural school students, $66.67 \%$ of them have high Level and $33.33 \%$ of them have moderate Level of social adjustment. The result inferred that majority of the urban and rural school students have high level of social adjustment. But comparatively, the rural school students have high level of social adjustment than the urban school students.

\section{Conclusion}

- Majority of the boys and girls have high level of social adjustment. But comparatively, the girls have high level of social adjustment than the boys.

- Majority of the Tamil and English medium have high level of social adjustment. But comparatively, the Tamil medium students have high level of social adjustment than the English medium students.

- Majority of the urban and rural school students have high level of social adjustment. But comparatively, the rural school students have high level of social adjustment than the urban school students. 
- There is no significant difference towards social adjustment based Mother Tongue, Gender, Medium of instruction, location of the school, type of the school, nature of the school, educational qualification of father, educational qualification of mother, monthly income of father, monthly income of mother, type of family.

\section{References}

[1] Agarwal,Y.P(2006) Statistical Methods, Concepts, Application and imputation, sterling Publishers(P) Ltd, New Delhi.

[2] Corey E. Ray et al. (2017). Social Adjustment and Academic Achievement: A Predictive Model for Students With Diverse Academic and Behavior Competencies. School Psychology Review. 35 (3), 493-501.

[3] Desh, B.N and Desh, N(2002) education Measurement statistics and guidance, Dominant Publishers, New Delhi.

[4] Narjes Safari et al. (2014). Assessment of Social Adjustment and Academic Achievement of Boys and Girls of Preschool during 2013-2014. International Conference on Arts, Economics and Management. 1 (3), 23-27.

[5] Soheila Yengimolki et al. (2015). Self-Concept, Social Adjustment and Academic Achievement of Persian Students. International Review of Social Sciences and Humanities. 8 (2), 50-60.

[6] Vijayalakshmi, R 1991, “A relationship between self-concept and personality adjustment of family- reared and institution and institution-neared children", Madurai Kamaraj University. 